\title{
Max Engammare, Un chaînon manquant: le «Kalendrier historial» de Conrad Bade (1555)
}

\section{Filippo Fonio}

\section{(2) OpenEdition}

1 Journals

\section{Edizione digitale}

URL: http://journals.openedition.org/studifrancesi/27397

DOI: 10.4000/studifrancesi.27397

ISSN: 2421-5856

\section{Editore}

Rosenberg \& Sellier

\section{Edizione cartacea}

Data di pubblicazione: 31 décembre 2006

Paginazione: 590

ISSN: 0039-2944

\section{Notizia bibliografica digitale}

Filippo Fonio, « Max Engammare, Un chaînon manquant: le "Kalendrier historial» de Conrad Bade (1555)», Studi Francesi [Online], 150 (L | III) | 2006, online dal 30 novembre 2015, consultato il 08 novembre 2020. URL : http://journals.openedition.org/studifrancesi/27397 ; DOI : https://doi.org/10.4000/ studifrancesi.27397

\section{Questo documento è stato generato automaticamente il 8 novembre 2020}

\section{(c) (1)}

Studi Francesi è distribuita con Licenza Creative Commons Attribuzione - Non commerciale - Non opere derivate 4.0 Internazionale. 


\title{
Max Engammare, Un chaînon manquant: le «Kalendrier historial» de Conrad Bade (1555)
}

\author{
Filippo Fonio
}

\section{NOTIZIA}

MAX ENGAMMARE, Un chainon manquant: le «Kalendrier historial» de Conrad Bade (1555), «Bibliothèque d'Humanisme et Renaissance», LXVII, 3 (2005), pp. 641-652.

1 Approfondendo le osservazioni sulla storia dei calendari protestanti già contenute nel recente L'Ordre du temps (Genève, 2004), Engammare studia un esemplare del Kalendrier historial di Conrad Bade figlio di Josse, edito alla fine dell'estate del 1555, rinvenuto da Jean-François Gilmont alla Bibliothèque municipale di Grenoble. Esule parigino, Bade ottiene nel 1554 un privilegio quinquennale per la pubblicazione di calendari dalle autorità municipali di Genève, fiduciose di potersi finalmente avvalere di un editore in grado di realizzare un almanacco che si presti a informare un'utenza riformata su ricorrenze e liturgia. Il Kalendrier di Bade sarebbe "l'anello mancante" fra il modello latino, l'Ephemeris historica di Gilbert Cousin (1552, ma edito alla fine dell'estate dell'anno precedente, com'era uso per i calendari), e gli almanacchi ginevrini stampati a partire dal 1560. Già nel calendario di Bade inizia il processo che porterà una forte diminuzione dell'importanza di episodi biblici negli almanacchi, a favore della rievocazione di fatti e figure della storia ugonotta e della versificazione dei Salmi. 